\title{
A Novel Peptide from T-Cell Leukemia Translocation-Associated Gene (TCTA) Protein Inhibits Proliferation of a Small-Cell Lung Carcinoma
}

\author{
Shigeru Kotake*, Toru Yago, Manabu Kawamoto, Yuki Nanke \\ Institute of Rheumatology, Tokyo Women's Medical University, Shinjuku, Japan. \\ Email: " ${ }^{2}$ kotake@ior.twmu.ac.jp \\ Received June $16^{\text {th }}, 2013$; revised July $25^{\text {th }}, 2013$; accepted August $3^{\text {rd }}, 2013$ \\ Copyright (C) 2013 Shigeru Kotake et al. This is an open access article distributed under the Creative Commons Attribution License, \\ which permits unrestricted use, distribution, and reproduction in any medium, provided the original work is properly cited.
}

\begin{abstract}
In 2009, we demonstrated that a peptide, which we named "Peptide A", derived from the extracellular domain of T-cell leukemia translocation-associated gene (TCTA) protein, inhibited both RANKL-induced human osteoclastogenesis and pit formation of mature human osteoclasts. Here, we examined the effect of Peptide A on the cell proliferation of cell lines of small-cell lung carcinoma, breast cancer, and prostate cancer: RERF-LC-MA, MCF-7, and PC-3, respectively. Peptide A inhibited the proliferation of RERF-LC-MA, but not MCF-7 or PC-3. TCTA protein was immunohistologically detected in RERF-LC-MA and MCF-7. Thus, Peptide A may provide a novel strategy for the therapy of the patients with small-cell lung carcinoma, especially with bone metastasis. In addition, Peptide A may be useful for the treatment of various cancer patients with bone metastasis.
\end{abstract}

Keywords: Osteoclast; Small-Cell Lung Carcinoma; TCTA

\section{Introduction}

In 1995, Aplan et al. cloned and characterized a novel gene at the site of a $\mathrm{t}(1 ; 3)(\mathrm{p} 34 ; \mathrm{p} 21)$ translocation breakpoint in T-cell acute lymphoblastic leukemia, designating this gene as TCTA [1]. TCTA mRNA is expressed ubiquitously in normal tissues, with the highest levels of expression in the kidney. TCTA has been conserved throughout evolution in organisms ranging from Drosophila to humans. A short open reading frame encodes a protein of 103 amino acid residues, Mr 11,300, without strong homology to any previously reported proteins. Of note, genomic Southern blots demonstrated a reduced TCTA signal in three of four small cell lung cancer cell lines, suggesting the loss of one of the two copies of the gene [1]. On the other hand, in 2005, it was reported that TCTA interacts with SMA- and MAD-related protein 4 (SMAD4) in a proteome-scale map of the human protein-protein interaction network (Supplementary Table S2, line 6175 of Ref. [2]); however, the function of TCTA has not been clarified.

In 2009, we identified a novel peptide expressed in synovial tissues of patients with RA that regulates human

"Corresponding author. osteoclastogenesis. We therefore purified proteins from synovial tissues of patients with RA, using gel filtration chromatography, reverse-aspect HPLC, and mass spectrometry [3]. We finally demonstrated that a peptide derived from the extracellular domain of TCTA protein inhibited both RANKL-induced human osteoclastogenesis and pit formation of mature human osteoclasts [3].

In the current study, we investigated the effect of a peptide form TCTA protein on the proliferation of RERFLC-MA, a small-cell lung carcinoma cell line. The peptide significantly inhibited the proliferation of RERFLC-MA.

\section{Materials and Methods}

\subsection{Cell Lines}

A human small cell carcinoma cell line, RERF-LC-MA, a prostate cancer cell line, PC-3, and a breast cancer cell line, MCF-7, were purchased from Health Science Research Resources Bank (Tokyo, Japan).

\subsection{Cell Proliferation Assay}

Cell proliferation of cancer cell lines was measured using 
a Cell Proliferation Assay Kit (XTT baser) (BIOLOGICAL INDUSTRES Ltd. Israel). The assay was performed according to manufacturer's protocol. Cells $(0.6-1.0 \times$ $10 \mathrm{E} 3 /$ well) were cultured in 96-well plates. Before cells were confluent, various concentrations of Peptide A or scrambled peptide as a control were added to the wells. After 24 or $48 \mathrm{hrs}$, the cells were collected, and cell proliferation was measured using the kit. Experiments were repeated 5 times. All experiments were performed in quadricate.

\subsection{RT-PCR for TCTA mRNA in Cell Lines}

We detected mRNA of TCTA using RT-PCR in each cell line incubated with Peptide A or the scrambled peptide. Each cell line $(1-2 \times 10 \mathrm{E} 3)$ was cultured using D-MEM with $10 \%$ of FCS in 6-well plates. After $24 \mathrm{~h}$, the medium was exchanged to D-MEM with $1 \%$ FCS and 2 $\mathrm{mM} \mathrm{L}$-glu. After another $24 \mathrm{~h}$, the medium was changed and peptide A or the scrambled peptide was added. After a further $24 \mathrm{~h}$, total RNA was prepared from the cells cultured as described above. A sense primer and an antisense primer were used under the PCR conditions, as previously described [3].

\subsection{Immunohistological Staining}

Cell lines were cultured using Lab-Tec chambers (Nunc, Narita, Japan). Immunohistological staining was performed as described previously (4). Anti-TCTA antibody \#1 was used as the 1st antibody to detect TCTA protein in cell lines; as previously reported, we obtained 2 polyclonal antibodies against TCTA, \#1 and \#2 [3]. Rabbit IgG was used as a control antibody. The bound antibodies were visualized as described previously [4]. Stained tissues were examined using one-box microscopy (BZ-
9000; Keyence, Osaka, Japan).

\section{Results}

\subsection{Peptide A Significantly Inhibited the Proliferation of RERF-LC-MA}

Peptide A dose-dependently inhibited the proliferation of RERF-LC-MA (Figure 1(a)). On the other hand, the scrambled peptide as a control did not inhibit the proliferation of RERF-LC-MA (Figure 1(b)). At $10 \mu \mathrm{g} / \mathrm{ml}$, Peptide A significantly inhibited the proliferation of RERFLC-MA compared with the scrambled peptide (Wilcoxon test, $p=0.031$, Figure 1(c)). Peptide A did not inhibit the proliferation of PC-3 or MCF-7 (data not shown).

\subsection{Immunohistological Staining for TCTA Protein}

TCTA proteins were immunohistologically detected in RERF-LC-MA and MCF-7 (Figure 2). In the current study, it was difficult to detect PC-3 specifically, because non-specific staining was strongly detected (data not shown).

\subsection{TCTA mRNA in Cell Lines}

Experiments were performed using 5 treatment conditions: 1) None, 2) $10 \mathrm{mg} / \mathrm{ml}$ peptide A, 3) $5 \mathrm{mg} / \mathrm{ml} \mathrm{pep-}$ tide A, 4) $10 \mathrm{mg} / \mathrm{ml}$ scrambled peptide, 5) $5 \mathrm{mg} / \mathrm{ml} \mathrm{scram}$ bled peptide in each cell lines. TCTA mRNA\% expressions were as follows: MCF-7, 1) $100.0,2) 113.5,3$ ) 102.4 , 4) 109.4, 5) 100.3; PC3, 1) 100.0, 2) 82.9, 3) 106.4 , 4) 86.9, 5) 72.3; RERF-LC, 1) 100.0, 2) 114.8, 3) 129.7 , 4) 115.1 , 5) 108.9. There was no tendency that peptide A changed the level of TCTA mRNA compared with the scrambled peptide.

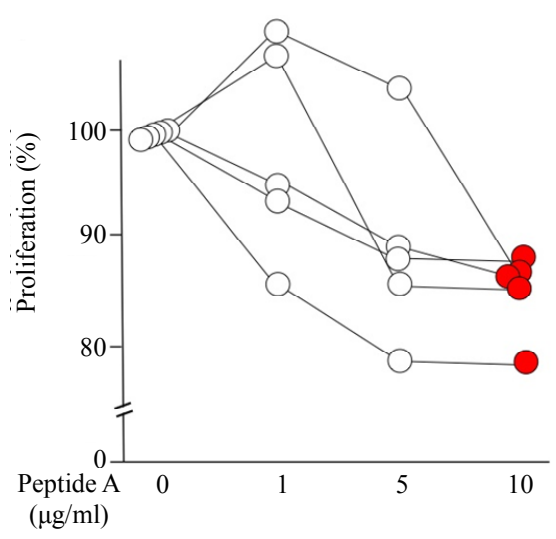

(a)

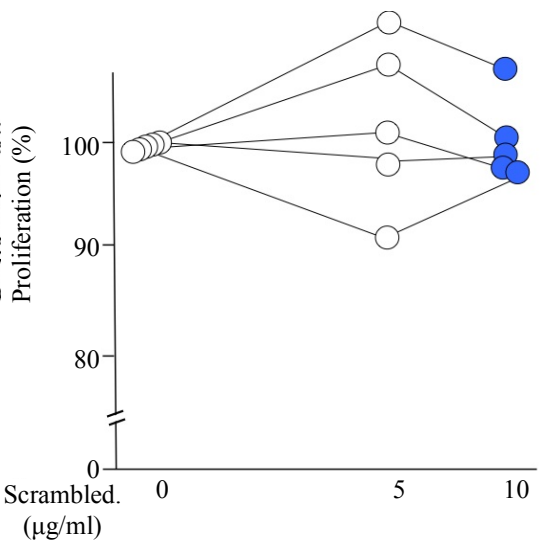

(b)

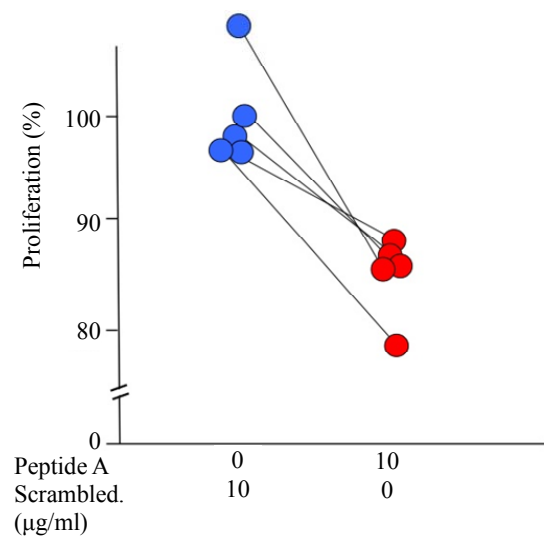

(c)

Figure 1. Cell proliferation assay. RERF-LC-MA was cultured with various concentration of Peptide A (a) or scrambled peptides (b). The proliferation levels with $10 \mu \mathrm{g} / \mathrm{ml}$ are shown red and blue for Peptide $A$ and scrambled peptides, respectively. The proliferation levels with $10 \mu \mathrm{g} / \mathrm{ml}$ are compared between Peptide A (red) and scrambled peptide (blue) in (c). 

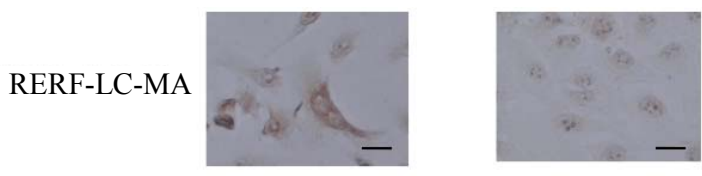

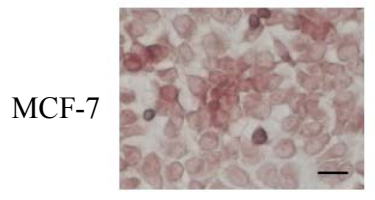

anti-TCTA Ab

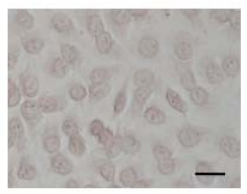

Rabbit IgG
Figure 2. Immunohistological detection of TCTA protein in cell lines. Bar: $10 \mu \mathrm{m}$.

\section{Discussion}

In the current study, we demonstrated that Peptide A significantly inhibited the cell proliferation of a smallcell lung carcinoma cell line, RERF-LC-MA. In addition, TCTA protein was detected in RERF-LC-MA. On the other hand, Peptide A did not change the level of TCTA mRNA in RERF-LC-MA. We previously demonstrated that toxicity is not detected in human cells cultured with peptide A [3]. Thus, our findings suggest that Peptide A is useful in the treatment of patients with small-cell lung carcinoma, although the mechanism of the inhibition remains to be elucidated.

Peptide A may be useful for patients with small lung cell carcinoma showing bone metastasis. We have demonstrated that Peptide A inhibits the formation and function of osteoclasts [3]. In addition, we demonstrated that Peptide A inhibited the proliferation of RERF-LC-MA in the current study. Thus, Peptide A is a novel strategy for late-stage patients with bone metastasis.

Breast cancer shows bone metastasis. Recently, it has been reported that breast cancer cell lines induces osteoclastogenesis in a paracrine manner [5]. In the current study, the proliferation of a breast cell line, MCF-7, was not inhibited by adding Peptide A; however, Peptide A may be useful to treat patients with bone metastasis, because it inhibits human osteoclastogenesis as we previously reported [3].

In conclusion, Peptide A may provide a novel thera- peutic strategy for patients with small-cell lung carcinoma, especially with bone metastasis. In addition, Peptide A may be useful for the treatment of various cancer patients with bone metastasis.

\section{Acknowledgements}

We thank Ms. Hanae Kikuchi (Tokyo Women's Med. Univ.) for valuable technical assistance.

\section{REFERENCES}

[1] P. D. Aplan, B. E. Johnson, E. Russell, D. S. Chervinsky and I. R. Kirsch, "Cloning and Characterization of TCTA, a Gene Located at the Site of at $(1 ; 3)$ Translocation," Cancer Research, Vol. 55, No. 9, 1995, pp. 1917-1921.

[2] J. F. Rual, K. Venkatesan, T. Hao, T. Hirozane-Kishikawa, A. Dricot, N. Li, G. F. Berriz, F. D. Gibbons, M. Dreze, N. Ayivi-Guedehoussou, N. Klitgord, C. Simon, M. Boxem, S. Milstein, J. Rosenberg, D. S. Goldberg, L. V. Zhang, S. L. Wong, G. Franklin, S. Li, J. S. Albala, J. Lim, C. Fraughton, E. Llamosas, S. Cevik, C. Bex, P. Lamesch, R. S. Sikorski, J. Vandenhaute, H. Y. Zoghbi, A. Smolyar, S. Bosak, R. Sequerra, L. Doucette-Stamm, M. E. Cusick, D. E. Hill, F. P. Roth and M. Vidal, "Towards a Proteome-Scale Map of the Human Protein-Protein Interaction Network," Nature, Vol. 437, No. 7062, 2005, pp. 1173-1178. doi:10.1038/nature04209

[3] S. Kotake, Y. Nanke, M. Kawamoto, T. Yago, N. Udagawa, N. Ichikawa, T. Kobashigawa, S. Saito, S. Momohara, N. Kamatani and H. Yamanaka, "T-Cell Leukemia Translocation-Associated Gene (TCTA) Protein Is Required for Human Osteoclastogenesis," Bone, Vol. 45, No. 4, 2009, pp. 627-639. doi:10.1016/j.bone.2009.06.019

[4] S. Kotake, N. Udagawa, N. Takahashi, K. Matsuzaki, K. Itoh, S. Ishiyama, S. Saito, K. Inoue, N. Kamatani, M. T. Gillespie, T. J. Martin and T. Suda, "IL-17 in Synovial Fluids from Patients with Rheumatoid Arthritis Is a Potent Stimulator of Osteoclastogenesis," The Journal of Clinical Investigation, Vol. 103, No. 9, 1999, pp. 13451352. doi:10.1172/JCI5703

[5] J. Costa-Rodrigues, K. A. Moniz, M. R. Teixeira and M. H. Fernandes, "Variability of the Paracrine-Induced Osteoclastogenesis by Human Breast Cancer Cell Lines," Journal of Cellular Biochemistry, Vol. 113, No. 3, 2012, pp. 1069-1079. doi:10.1002/jcb.23439 